\title{
2
}

\section{Designing and Strengthening Local Government}

The specific design of decentralisation and local government (LG) differs in every country. Structure and organisation are affected by the historical, social and political context. In some countries there are a mixture of types of decentralisation and different institutional arrangements within a single country.

The resources below detail practical options for local government design as well as considerations for those wanting to strengthen LG through specific capacity building work.

\section{Designing LG structure}

Major challenges in the design of decentralisation reforms are allocating responsibilities between levels of government, designating territorial jurisdictions, establishing electoral arrangements, designing internal management structures and creating appropriate accountability mechanisms.

The generally accepted view is that a sector or function is a prime candidate for decentralisation if:

- local demands for a service differ across localities

- there are no substantial economies of scale associated with the service

- there are no substantial spillovers of costs or benefits from the service

- the service is amenable to at least partial local financing through taxes or charges

- local governments have the capacity to deliver the service

- the service is not meant to provide substantial redistribution of income or wealth

It is not possible to say that certain services should always, or should never, be decentralised. The resources below suggest that the specific context for reform is important (a one-size-fits-all approach is not appropriate) and that countries may need to take an incremental approach. 
Because decentralisation entails changes in institutional arrangements it affects power relations. It therefore typically creates two groups: those who benefit and are therefore likely to support reforms, and those who are likely to lose out politically or economically, and therefore may attempt to undermine the process.

Olowu, D., 2003, 'Local Institutional and Political Structures and Processes: Recent Experience in Africa', Public Administration and Development, vol. 23, pp. 41-52

Has decentralisation produced appropriate intergovernmental relational mechanisms for supporting strong and effective local governance? Has decentralisation led to the creation of effective self-governance structures at the community level? This paper by the Institute of Social Sciences (ISS) looks at the recent experience of democratic decentralisation in Africa.

Full summary available in alphabetical appendix or online at: http://www.gsdrc.org/go/display\&type=Document\&id=688

Turner, M., 2003, 'Issues in the Design of Decentralisation', in Schoeffler, P. and Turner, M., 'Local Level Governance in the Pacific', State, Society and Governance in Melanesia Discussion Paper 2003/7, Australian National University, Canberra How can the design of decentralisation programmes be improved? This study published by the Australian National University argues that good decentralisation design processes that address fundamental questions and are fully aware of political realities can lead to developmental gains. Although the initial design is very important, it is only the first step in the process of decentralisation and the promotion of good governance at the local level.

Full summary available in alphabetical appendix or online at:

http://www.gsdrc.org/go/display\&type=Document\&id=3324

There can often be a vast difference between the intended design of local government and what actually happens on the ground. This may be because of political interference or because of local level capacity constraints.

Andrews, M. and Schroeder, L., 2003, 'Sectoral Decentralisation and Intergovernmental Arrangements in Africa', Public Administration and Development, vol. 23, pp. 29-40

In the context of the key service sectors of primary health care and rural roads in subSaharan Africa, should decentralisation be used in the assignment of these services? How should decisions be made about which services to decentralise? When factors such as economies of scale or the need for nationally integrated and coordinated services like the road system are considered, how far should the decentralisation process be taken? This paper from the World Bank Institute and Syracuse University assesses these and further questions.

Full summary available in alphabetical appendix or online at:

http://www.gsdrc.org/go/display\& type=Document\&id=720 


\section{Central/local relations}

Ensuring good working relationships between central and local level government, and between tiers in a multi-tier system, is important for effective operations. Unfortunately, case studies often describe central/local relations as characterised by mistrust. A common source of tension arises from the level of control exerted by central government and the accountability expected of local government. Case studies describe local governments complaining of excessive control from central units, onerous accountability mechanisms, inadequate resourcing and political interference, all ultimately undermining the decentralisation of power. However, central government does have to retain involvement in LG affairs to ensure adequate accountability and proper use of resources. Designing accountability and co-ordination mechanisms to ensure balanced, harmonious central/local relations is therefore a difficult, but important, task.

Crook, R., 2003, 'Decentralisation and Poverty Reduction in Africa: The Politics of Local-Central Relations', Public Administration and Development, vol. 23, pp. $77-88$

Are decentralised forms of government necessarily more responsive to the needs of the poor, and thus more likely to pursue pro-poor policies? Evidence from a selected group of sub-Saharan African countries, examined in this contribution to Public Administration and Development, suggests that the answer depends on politics. The general regime and relations between local and central government are key factors in determining whether decentralisation helps reduce poverty.

Full summary available in alphabetical appendix or online at: http://www.gsdrc.org/go/display\& type=Document\&id=659

Panday, P. K., 2006, 'Central-Local Relations, Inter-Organisational Coordination and Policy Implementation in Urban Bangladesh', The Asia Pacific Journal of Public Administration, vol. 28, no. 1

What happens to policy implementation when the process suffers from problems of co-ordination? This article from the Asia Pacific Journal of Public Administration focuses on how central-local relations in Bangladesh create inter-organisational coordination problems that affect the implementation of policies in urban governance. In the Rajshahi City Corporation (RCC), the central-local relationship is determined by the political identity of the mayor. Competing pressures and demands of local autonomy and central control are weighted in favour of centralisation at the expense of local autonomy and initiative.

Full summary available in alphabetical appendix or online at: http://www.gsdrc.org/go/display\&type=Document\&id=3323 
Wunsch, J. 2001, 'Decentralization, Local Governance and Recentralization in Africa', in Public Administration and Development, vol. 21, pp. 277-288

Why have decentralisation reforms in Africa not produced the expected results? What causes the strong counter-current towards 'recentralisation'? Over the past 15 years, many African countries have invested in political and administrative reform aimed at increasing local governance. However, a reluctance of actors at central level to relinquish resources and decision making power to local entities has created a reverse current towards 'recentralisation'.

Full summary available in alphabetical appendix or online at:

http://www.gsdrc.org/go/display\& type=Document\&id=237

\section{Local level human resource management}

Effective management of human resources at the local level is critical for effective LG performance. There must be clear arrangements with central government for line management responsibilities, control over recruitment, performance assessment and the power to dismiss employees. There are three principle models:

- Local governments recruit and manage all staff - this is common in developed countries but rare in developing countries.

- Central government appoints senior staff and local governments appoint junior staff. This may help to ensure that competent staff are appointed at the local level and prevent discrimination against nonlocals, but it can undermine local accountability and create conflicts.

- Some form of Local Government Service Commission (LGSC) that oversees the appointment of local government staff (and perhaps transfers between local governments) The role of the LGSC may be directly involved in the appointment, promotion and transfer of staff, or more indirectly involved via monitoring of human resource management practices of local governments.

Green, A., 2005, 'Managing Human Resources in a Decentralized Context', Chapter 7 in ed. World Bank, East Asia Decentralizes: Making Local Government Work, World Bank, Washington D.C.

What are the implications of decentralisation for human resource management? How have governments in East Asia addressed the issue of civil service management in relation to decentralisation? Using case studies, this book chapter from the World Bank examines human resource management in decentralised contexts. It argues that human resource management should be seen as a central component in the design of decentralisation rather than a separate stand-alone process.

Full summary available in alphabetical appendix or online at:

http://www.gsdrc.org/go/display\& type=Document\&id=3360 
Evans, A with Manning, N., 2004, Administrative Decentralization: A Review of Staffing Practices in Eight Countries, World Bank, Washington D.C.

What impact do different dimensions of managerial control have on administrative decentralisation? What lessons can be learned from the paths taken by countries with relatively high levels of administrative decentralisation? This unpublished paper prepared for the World Bank examines staffing and managerial control within the context of decentralisation. Based on case studies of decentralisation in Benin, India, Indonesia, Mexico, Pakistan, the Philippines, Poland, and Uganda it proposes a framework for analysing managerial control.

Full summary available in alphabetical appendix or online at:

http://www.gsdrc.org/go/display\& type=Document\&id=3380

Lodge, G. and Kalitowski, S., 2007, 'Innovations in Government: International Perspectives on Civil Service Reform', Institute for Public Policy Research London

What are the challenges confronting civil services around the world? This paper from the Institute for Public Policy Research (IPPR) surveys several case studies from developed countries to identify a variety of international approaches to civil service reform. Some common challenges include: enhancing accountability; improving policy-making; developing institutional memory; building staff expertise; and promoting joined-up government. Meeting these challenges requires clarifying the roles of ministers and officials, opening up policy-making, capturing innovation and narrowing the gap between the centre and frontline delivery services.

Full summary available in alphabetical appendix or online at:

http://www.gsdrc.org/go/display\& type=Document\&id=2776

\section{Building capacity}

It is important that each level of government has sufficient capacity to carry out the responsibilities transferred via decentralisation reforms. Local governments are often criticised for having weak capacity, for example in the areas of public financial management or planning. Initiatives to assess and develop capacity are therefore important parts of decentralisation strategies.

UNCDF, 2005, 'Building Local Government Capacity to Achieve the Millennium Development Goals: A Practitioner's Guide from UNCDF Experience in Least Development Countries', United Nations Capital Development Fund, New York How can local development programmes (LDPs) build the capacity of local governments and local organisations in order to improve their performance? This guide from the United Nations Capital Development Fund presents lessons and guidelines for local government capacity-building in development programmes. It addresses LDP strategy, financing strategy, local public investment expenditure management, 
and accountability, communications and information. This summary focuses on chapter five of the guide, 'Capacity Building'.

Full summary available in alphabetical appendix or online at:

http://www.gsdrc.org/go/display\&type=Document\&id=3358

\section{UNDP, 2008, 'Capacity Development', Practice Note, UNDP, New York}

What are the core capacity issues in a development context? How can external partners support countries' efforts to build on these to achieve development goals? This Practice Note, written by the United National Development Programme (UNDP), addresses these issues, drawing on examples from a range of developing countries. It sets out key entry points for UNDP and other external actors to promote capacity development (CD) arguing that UNDP should focus primarily on supporting key cross-cutting capacities.

Full summary available in alphabetical appendix or online at: http://www.gsdrc.org/go/display\&type=Document\&id=1870

Hadingham, T., 2003, 'Decentralisation and Development Planning: Some Practical Considerations', Department for International Development (DFID)

How can high level strategic thinking and local participation be brought together for optimum outcomes? How can the different dynamics of national Poverty Reduction Strategies and decentralisation work together effectively? This report, commissioned by the Infrastructure and Urban Development Department of the UK Department for International Development, identifies ways in which planning systems can integrate national strategic goals with the outcomes of local participatory processes.

Full summary available in alphabetical appendix or online at:

http://www.gsdrc.org/go/display\& type=Document\&id=980

\section{Case studies}

- Duncan, R., 2004, 'An Overview of Decentralisation and Local Governance Structures in the Pacific Region', paper presented to the Pacific Regional Symposium 'Making Local Governance Work' organised by the Commonwealth Local Government Forum Pacific Project, Fiji, 4-8 December, 2004. http://www.usp.ac.fj/fileadmin/files/Institutes/piasdg/governance_papers/ duncan_decentralisation.pdf

- Nickson, A., et al, 2007, 'Global Reports on Decentralisation and Local Democracy: Asia-Pacific', United Cities and Local Government http://www.citieslocalgovernments.org/gold/Upload/gold_report/ 03_asiapacific_en.pdf 
- Fjeldstad, O-H., et al., 2006, 'Local Government Reform in Tanzania 2002-2005: Summary of Research Findings on Governance, Finance and Service Delivery', Research on Poverty Alleviation (REPOA) Brief 6, October, REPOA http://www.gsdrc.org/go/display\&type=Document\&id=2612

\section{Other resources}

- GSDRC topic guide on civil service reform in developing countries http://www.gsdrc.org/go/topic-guides/civil-service-reform

- World Bank webpage on Administrative Decentralisation http://www1.worldbank.org/publicsector/decentralization/admin.htm\#3

- Royal Tropical Institute (KIT) dossier on Capacity Development for Governance and Decentralization http://www.kit.nl/smartsite.shtml?ch=FAB\&id=30333

- EuropeAid, 2007, 'Supporting Decentralisation and Local Governance in Third Countries', Tools and Methods series, Reference document 2, European Commission, Brussels.

http://ec.europa.eu/europeaid/what/governancedemocracy/documents/ decentralisation_local_governance_refdoc_final_en.pdf 
